\title{
Research Article \\ The Trichoptera Fauna of Ulupınar Stream and Its Relationship with Water Quality
}

\section{Ulupınar Çayı'nın Trichoptera Faunası ve Su Kalitesi ile İlişkisi}

\author{
Aynur Kayan* \\ Department of Biology, Faculty of Science and Letters, Süleyman Demirel University, Isparta, \\ Turkey \\ ozenaynur7@gmail.com (https://orcid.org/0000-0002-9653-5506) \\ Received Date: 30.10.2020, Accepted Date: 08.12.2020
}

\begin{abstract}
In this study it was aimed to determine the Trichoptera fauna and water quality of Ulupinar Stream which is an important tourism destination of Antalya, based on physicochemical parameters. In recent years, this stream was adversely affected by intensive agriculture, farming and domestic wastes and was exposed to various pollutants. Seasonal analyses of physicochemical parameters and sampling of organisms belonging to the order Trichoptera were carried out from six stations selected between November 2015 and June 2016. 6 families, 10 genera and 21 species belonging to order Trichoptera were identified. Similarities between the sampling points were clustered by using Unweighted Pair Group Method with Arithmetic Mean. As a result of the Unweighted Pair Group Method with Arithmetic Mean. analysis, the $4^{\text {th }}$ and $6^{\text {th }}$ sampling point $(85 \%)$ were the most similar to each other. The Principal Component Analysis was used to determine the factors caused the pollution. The Principal Component Analysis was applied to only physicochemical data sets resulted in three principal components accounting for a cumulative variance of $80.9 \%$ of for Ulupinar Stream.
\end{abstract}

Keywords: Trichoptera, Ulupınar Stream, water quality, principle component analysis

\section{Öz}

Bu çalışmada Antalya’nın önemli bir turizm bölgesi olan Ulupınar Çayı'nın Trichoptera faunası ve su kalitesinin fizikokimyasal parametrelere göre belirlenmesi amaçlanmıştır. Son yıllarda bu çay yoğun tarım, çiftçilik faaliyetlerinden ve evsel atıklardan olumsuz etkilenmiş ve çeşitli kirletici maddelere maruz kalmıştır. Fizikokimyasal parametrelerin mevsimsel analizleri ve Trichoptera takımına ait organizmaların örneklenmesi Kasım 2015 ile Haziran 2016 tarihleri arasında seçilen altı istasyondan gerçekleştirildi. Trichoptera takımına ait 6 familya, 10 cins ve 21 tür tespit edildi. Örnekleme noktaları arasındaki benzerlikler Aritmetik Ortalamalı Ağırlıksız Çift Grup Yöntemi kullanılarak kümelenmiştir. Aritmetik Ortalamalı Ağırlıksız Çift Grup Yöntemi analizinin bir sonucu olarak, 4. ve 6. örnekleme noktaları (85\%) birbirine en çok benzeyen istasyon olmuştur. Kirliliğe neden olan faktörleri belirlemek için Temel Bileşen Analizi kullanıldı. Yalnızca fizikokimyasal veri setlerine uygulanan Temel Bileşen Analizi, Ulupınar Çayı'nın 80,9\%'unun kümülatif varyansını oluşturan üç ana bileşene neden olmuştur.

Anahtar kelimeler: Trichoptera, Ulupınar Çayı, su kalitesi, temel bileşen analizi

\footnotetext{
* Corresponding author
} 


\section{Introduction}

In many countries, the need for water increases while unpolluted water resources are decreasing as a result of the deterioration of usable water resources with various factors. Due to this situation, various policies were developed to ensure the correct use and protection of natural resources both in our country and in other world states. The EU Water Framework Directive (WFD) implemented by the member states of the European Union (EU) is one of these directives. According to WFD, benthic macroinvertebrates are considered as one of the most important indicators. Pauls et al. (2008) stated that among the important benthic macroinvertebrates living in streams, members of order Trichoptera are used as a biological monitoring tool in determining water quality. When sedimentation, industrial pollution, mining and agriculture, sewage waste, acid rains accumulate on the water surface, these organisms are damaged (Graf et al., 2008).

Order Trichoptera are represented approximately with 49 families, 616 genera and 14.548 species in the world (Morse, 2011). Order Trichoptera are represented by 22 families, 461 species and 39 subspecies in Turkey (Dar1lmaz \& Salur, 2015; Küçükbasmacı \& Kıyak, 2017; Sipahiler, 2018a). In Turkey, as well as various faunistic studies were conducted to uncover the Trichoptera fauna, in ecological-based studies, the members of this order have been widely investigated as biological indicators. (Çakın, 1983; Darılmaz \& Salur, 2015).

Ulupinar Stream, chosen as a study area, is flowed between Olimpos and Çrralı Bays in Antalya. Since the stream is flowed into the intensive tourism areas, many places such as pensions and restaurants are encountered on the stream or its edges.

This study aims to determine species of Trichoptera fauna of Ulupinar Stream, to determine the water quality used by physicochemical parameters and to examine the relationships between physicochemical parameters and Trichoptera species.

\section{Study Area}

\section{Method}

Ulupınar Stream, which has formed the Çıralı Plain and its coast, is born from the $900 \mathrm{~m}$ high slopes in the northwest of Ulupinar Village. The stream, springs from the karstic creeks, flows under the name of Hayıt Creek up to Kumluca - Antalya Highway, and then combines with Kuruseki Creek, coming from the east of Antalya with the branches of Cehennem Creek from the west of Antalya, and flows by name 
of Ulupinar Stream. The total length of the stream flowing in a tectono-karstic groove, is about $13 \mathrm{~km}$.

The outfall section, where Ulupinar Stream disombogues into the Mediterranean Sea, generally turns north and sometimes turns south. Since the dominant wind on the shore blows from the southeast direction, the outfall of the stream is mostly shifted to the north. Although plane tree is the dominant vegetation of the valley floor of Ulupinar Stream, and on the slopes of the valley, the dominant vegetation is red pine, almost all species of maquis are common. The characteristics of sampling stations were presented in Table 1.

\section{Collection of Trichoptera Samples}

Samples were collected by 20 minutes by kicking and sweeping methods with kick-net $(250 \mu \mathrm{m}$ mesh). The samples were taken from several different sections at each station in order to include all possible microhabitats. All the samples collected were immediately fixed in formaldehyde $(4 \%)$ in the field. Trichoptera individuals were taken to SDU Hydrobiology Laboratory and stored in $70 \%$ alcohol. The obtained samples were examined under a stereomicroscope and evaluated qualitatively and quantitatively.

Edington \& Hildrew (1995), Pitsch (1993), Pescador et al. (1995), Wallace et al. (1990), Wiggins (1998), Waringer \& Graf (2011) were used in species diagnoses.

\section{Table 1}

Key Characteristics of Sampling Stations across Ulupınar Stream

\begin{tabular}{|c|c|c|c|c|}
\hline Sampling Station & Coordinates (N-E) and Altitude (m) & Habitat & Stream Morphology & Riparian Vegetation \\
\hline 1 & $\begin{array}{c}36^{\circ} 27^{\prime} \mathrm{N} 30^{\circ} 26^{\prime} \mathrm{E} \\
245 \mathrm{~m}\end{array}$ & Macrolithal & Macrophyte present & $\begin{array}{l}\text { Well-developed on } \\
\text { both sides. }\end{array}$ \\
\hline 2 & $\begin{array}{c}36^{\circ} 27^{\prime} \mathrm{N} 30^{\circ} 26^{\prime} \mathrm{E} \\
246 \mathrm{~m}\end{array}$ & Microlithal & Macrophyte present & $\begin{array}{l}\text { Well-developed on } \\
\text { both sides. }\end{array}$ \\
\hline 3 & $\begin{array}{c}36^{\circ} 26^{\prime} \mathrm{N} 30^{\circ} 26^{\prime} \mathrm{E} \\
265 \mathrm{~m}\end{array}$ & Macrolithal & Macrophyte present & Not well- developed \\
\hline 4 & $\begin{array}{c}36^{\circ} 27^{\prime} \mathrm{N} 30^{\circ} 26^{\prime} \mathrm{E} \\
201 \mathrm{~m}\end{array}$ & Megalithal & $\begin{array}{c}\text { No Macrophyte } \\
\text { present }\end{array}$ & Not well- developed \\
\hline 5 & $\begin{array}{c}36^{\circ} 27^{\prime} \mathrm{N} 30^{\circ} 25^{\prime} \mathrm{E} \\
186 \mathrm{~m}\end{array}$ & Macrolithal & Macrophyte present & Not well- developed \\
\hline 6 & $\begin{array}{c}36^{\circ} 25^{\prime} \mathrm{N} 30^{\circ} 26^{\prime} \mathrm{E} \\
54 \mathrm{~m}\end{array}$ & Microlithal & Macrophyte present & Not well- developed \\
\hline
\end{tabular}




\section{Physicochemical Parameters}

$1 \mathrm{~L}$ polyethylene sample containers were used for water sample collection. Water samples were taken seasonally between November 2015 and June 2016 from each of the 6 stations. I paid attention to take the samples concurrently.

Water temperature $\left({ }^{\circ} \mathrm{C}\right), \mathrm{pH}$, electrical conductivity (EC) $\mu \mathrm{S} / \mathrm{cm}$ and dissolved oxygen (DO) $\mathrm{mg} / \mathrm{L}$ were measured in the field by using a portable multiparameter (YSI 550A) device. Ammonium nitrogen $\left(\mathrm{NH}_{4}-\mathrm{N}\right) \mathrm{mg} / \mathrm{L}$, Nitrite nitrogen $\left(\mathrm{NO}_{2}-\mathrm{N}\right) \mathrm{mg} / \mathrm{L}$, Nitrate nitrogen $\left(\mathrm{NO}_{3}-\mathrm{N}\right) \mathrm{mg} / \mathrm{L}$, Ortho-phosphate ion $\left(\mathrm{PO}_{4}-\right.$ P) $\mathrm{mg} / \mathrm{L}$, Chloride Ion $\left(\mathrm{Cl}^{-}\right) \mathrm{mg} / \mathrm{L}$, Biological oxygen demand $\left(\mathrm{BOI}_{5}\right)(\mathrm{mg} / \mathrm{L})$ were analysed at the University of Süleyman Demirel, Geothermal Energy, Groundwater and Mineral Resources Research and Application Centre.

In this study, physicochemical water quality was determined according to Klee (1991) methods and the Turkish Regulation for Water Pollution Control (WPCR) (2008) of the Ministry of Forestry and Water Management of the Republic of Turkey.

\section{Data Analysis}

The faunal similarities based on Trichoptera fauna between the sampling stations were assessed by using the Bray-Curtis similarity index (Sommerfield, 2008; Yoshioka, 2008). UPGMA analysis based on Bray-Curtis similarity index was applied by using the PAST3 software program. All mathematical and statistical analyses on the physicochemical and biological data sets were made by using Excel 2019 (Microsoft Office $^{\mathrm{R}}$ ) (Kazi et al., 2009).

Principal Component Analysis (PCA) is a statistical procedure that uses an orthogonal transformation to convert the observation set of interrelated variables into the values of linearly unrelated variables called principal components. In this study, PCA analysis was used to evaluate the statistical correlation between physicochemical variables in Ulupınar Stream.

\section{Results}

\section{Physicochemical Variables}

The physicochemical variables were recorded seasonally. The maximum, average and minimum recorded values at the stations are given in Table 2. 


\section{Table 2}

Minimum, Average and Maximum Values of Physicochemical Parameters at the Six Stations in Ulupinar Stream

\begin{tabular}{cccccccccccc}
\hline & & $\mathrm{DO}$ & $\mathrm{pH}$ & $\mathrm{T}^{\circ} \mathrm{C}$ & $\mathrm{EC}$ & $\mathrm{Cl}^{-}$ & $\mathrm{NH}_{4}-\mathrm{N}$ & $\mathrm{NO}_{2}-\mathrm{N}$ & $\mathrm{NO}_{3}-\mathrm{N}$ & $\mathrm{PO}_{4}-\mathrm{P}$ & $\mathrm{BOD}_{5}$ \\
\hline \multirow{2}{*}{1} & Min. & 6.31 & 7.47 & 10.9 & 269.5 & 5.15 & $<0.05$ & $<0.01$ & 0.09 & $<0.05$ & 0.10 \\
& Avg. & 8.60 & 7.84 & 16.4 & 355.6 & 9.35 & $<0.05$ & $<0.01$ & 0.22 & $<0.05$ & 1.69 \\
& Max & 9.91 & 8.11 & 19.7 & 451.0 & 19.95 & $<0.05$ & $<0.01$ & 0.41 & $<0.05$ & 3.52 \\
\hline \multirow{2}{*}{2} & Min. & 6.17 & 8.03 & 11.5 & 272.0 & 5.87 & $<0.05$ & $<0.01$ & 0.28 & $<0.05$ & 0.59 \\
& Avg. & 8.01 & 8.28 & 16.6 & 297.1 & 8.04 & $<0.05$ & $<0.01$ & 1.20 & $<0.05$ & 1.88 \\
& Max & 9.26 & 8.5 & 21.9 & 333.1 & 10.52 & 0.06 & $<0.01$ & 2.98 & $<0.05$ & 3.24 \\
\hline \multirow{2}{*}{3} & Min. & 6.57 & 7.97 & 12.5 & 237.6 & 5.84 & $<0.05$ & $<0.01$ & 0.24 & $<0.05$ & 0.54 \\
& Avg. & 8.40 & 8.19 & 15.0 & 258.4 & 6.32 & $<0.05$ & $<0.01$ & 0.34 & $<0.05$ & 2.42 \\
& Max & 9.24 & 8.46 & 16.1 & 286.4 & 6.96 & 0,10 & $<0.01$ & 0.61 & $<0.05$ & 3.75 \\
\hline \multirow{2}{*}{4} & Min. & 6.73 & 7.94 & 12.1 & 291.1 & 6.34 & $<0.05$ & $<0.01$ & 0.13 & $<0.05$ & 0.56 \\
& Avg. & 8.68 & 8.15 & 16.3 & 327.9 & 7.20 & $<0.05$ & $<0.01$ & 0.30 & $<0.05$ & 2.40 \\
& Max & 9.80 & 8.37 & 19.8 & 385.2 & 8.54 & $<0.05$ & $<0.01$ & 0.48 & $<0.05$ & 4.00 \\
\hline & Min. & 8.44 & 7.77 & 12.9 & 219.0 & 5.57 & $<0.05$ & $<0.01$ & 0.15 & $<0.05$ & 2.31 \\
& Avg. & 9.18 & 8.15 & 13.9 & 236.4 & 7.53 & $<0.05$ & $<0.01$ & 0.24 & $<0.05$ & 3.03 \\
& Max & 9.99 & 8.41 & 14.6 & 258.6 & 12.64 & $<0.05$ & $<0.01$ & 0.31 & $<0.05$ & 4.00 \\
\hline \multirow{2}{*}{6} & Min. & 6.01 & 7.95 & 12.2 & 320.1 & 14.89 & $<0.05$ & $<0.01$ & 0.02 & $<0.05$ & 0.65 \\
& Avg. & 7.79 & 8.08 & 19.5 & 427.4 & 16.9 & $<0.05$ & $<0.01$ & 0.26 & $<0.05$ & 2.04 \\
& Max & 9.52 & 8.27 & 24.3 & 500.0 & 19.58 & $<0.05$ & $<0.01$ & 0.58 & $<0.05$ & 3.75 \\
\hline
\end{tabular}

When minimum, average and maximum values of physicochemical parameters were evaluated, it was found that the Dissolved Oxygen (DO) values varied with the stations and seasons. Its average values were fluctuated between 7.79 $\mathrm{mg} / \mathrm{L}$ (station 6) and $9.18 \mathrm{mg} / \mathrm{L}$ (station 5). Average $\mathrm{pH}$ values were close to each other for 6 stations and all seasons. The lowest average $\mathrm{pH}$ value was measured at $1^{\text {st }}$ station with 7.84 , and the highest average value was measured at $2^{\text {nd }}$ station with 8.28. The average values of the $\mathrm{BOD}_{5}$ in the station 5 had the highest value with 3.03 $\mathrm{mg} / \mathrm{L}$ and in the station 1 it had the the lowest value with $1.69 \mathrm{mg} / \mathrm{L}$ while the electrical conductivity (EC) values were varied between $236.4 \mu \mathrm{S} / \mathrm{cm}$ (station 5) $427.4 \mu \mathrm{S} / \mathrm{cm}$ (station 6). The highest ammonium nitrogen $\left(\mathrm{NH}_{4}-\mathrm{N}\right)$ in Ulupinar Stream was measured as $0.10 \mathrm{mg} / \mathrm{L}$ at the $3^{\text {rd }}$ station. $\mathrm{NH}_{4}-\mathrm{N}$ value was measured as $<0.05 \mathrm{mg} / \mathrm{L}$ at all other stations. It has been determined that nitrite nitrogen $\left(\mathrm{NO}_{2}-\mathrm{N}\right)$ $(<0.01 \mathrm{mg} / \mathrm{L})$ and ortho phosphate $\left(\mathrm{PO}_{4}-\mathrm{P}\right)(<0.05 \mathrm{mg} / \mathrm{L})$ values were below the analysis limits. The measured values of nitrate nitrogen $\left(\mathrm{NO}_{3}-\mathrm{N}\right)$ differed by stations and seasons. Average values were determined between $0.22 \mathrm{mg} / \mathrm{L}$ (station 1) and $0.34 \mathrm{mg} / \mathrm{L}$ (station 3). The average chloride $\left(\mathrm{Cl}^{-}\right)$ion values varied between 6.32 $\mathrm{mg} / \mathrm{L}$ (station 3) - $16.9 \mathrm{mg} / \mathrm{L}$ (station 6). 
The result of the correlation matrix of physicochemical components based on PCA and the biplots, which are the graphical representation of factor loadings in different components (Component 1, Component 2 and Component 3 ) are given in Figure 1. The PCA was applied on 10 physicochemical parameters for Ulupinar Stream with six sampling stations to determine the variations in water quality. In this study, the eigenvalues were greater than 1 at Component 1, Component 2 and Component 3. The PCA analysis led to the explanation of $80.9 \%$ variance in case of Ulupinar Stream. According to Liu et al. (2003), the factor loadings classified as "strong", "moderate" and "weak" corresponding to precise loading values of $>0.75$, $0.75-0.50$ and $0.50-0.30$, respectively.

\section{Figure 1}

Biplots for PCA analysis of physicochemical water quality in Ulupinar Stream
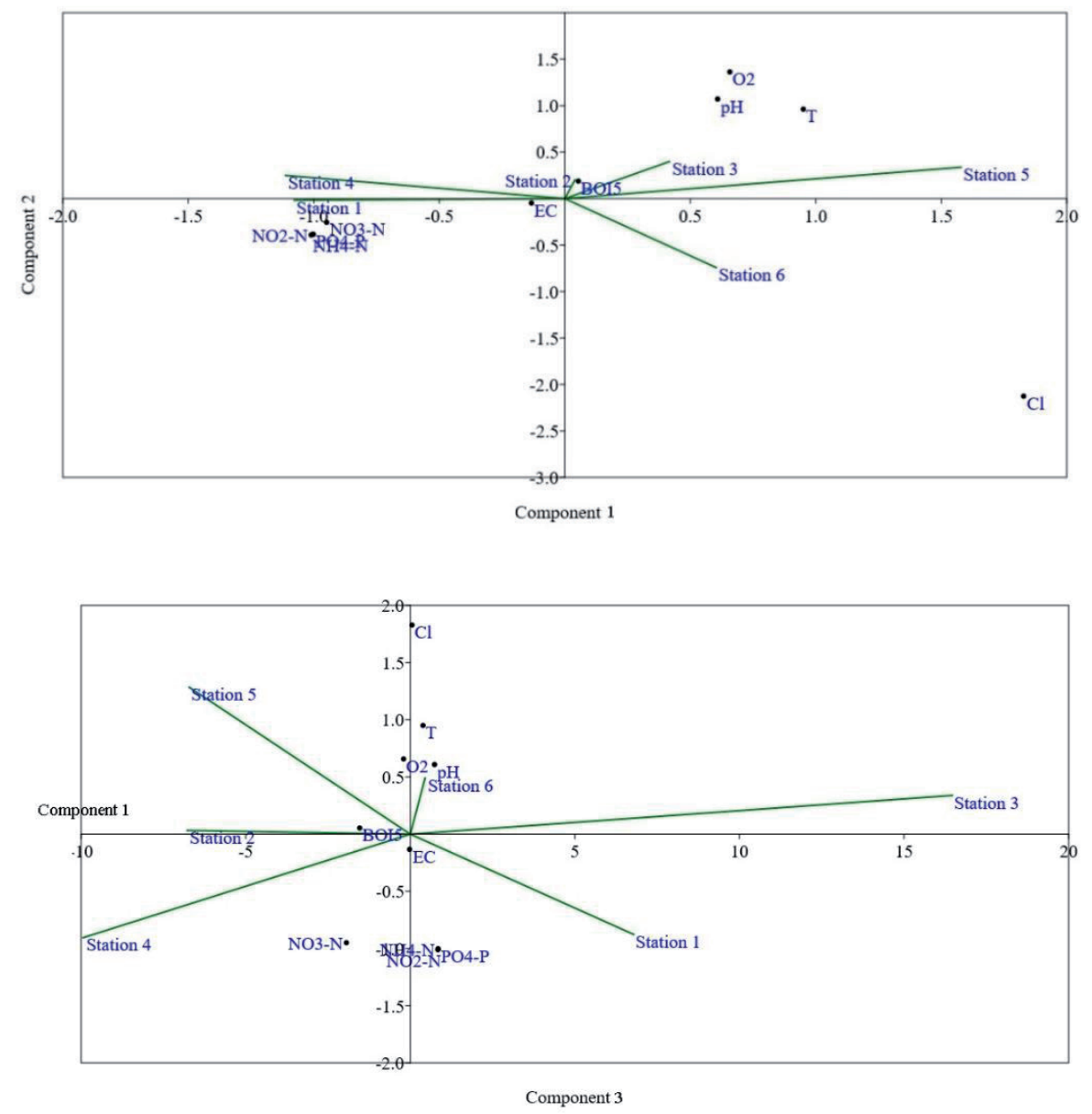


\section{Figure 1}

\section{(Continued)}

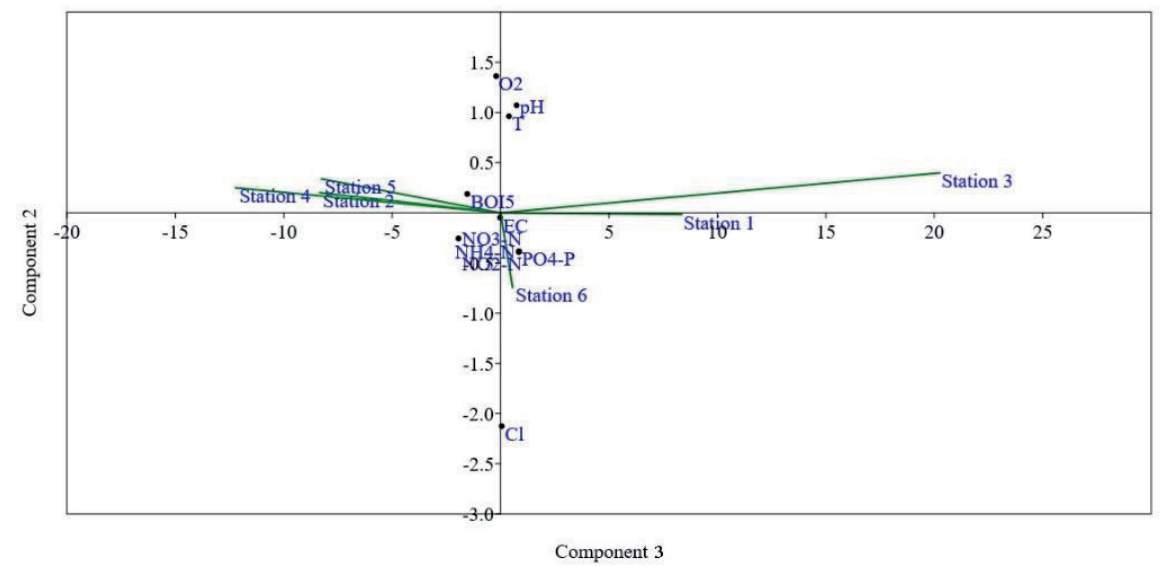

According to the data set pertaining from Ulupinar Stream, among three PCs, the Component 1 explaining $67.7 \%$ of the total variance ha strong positive loading on $\mathrm{T}^{\circ} \mathrm{C}$, and $\mathrm{Cl}^{-}$, moderate positive loading on $\mathrm{DO}, \mathrm{BOI}_{5}$ and $\mathrm{pH}$ whereas negative strong loading on $\mathrm{NH}_{4}-\mathrm{N}, \mathrm{NO}_{3}-\mathrm{N}, \mathrm{NO}_{2}-\mathrm{N}$ and $\mathrm{PO}_{4}-\mathrm{P}$. The positive loading on $\mathrm{T}^{\circ} \mathrm{C}$, $\mathrm{Cl}^{-}, \mathrm{DO}, \mathrm{BOI}_{5}$ and $\mathrm{pH}$ have been related to pollution. According to Solanki et al. (2010), the opposite relationship between $\mathrm{T}^{\circ} \mathrm{C}$ and $\mathrm{NH}_{4}-\mathrm{N}, \mathrm{NO}_{3}-\mathrm{N}, \mathrm{NO}_{2}-\mathrm{N}$ and $\mathrm{PO}_{4}-$ $\mathrm{P}$ are a natural process in freshwaters. According to Component 2, 30.8\% of total variance has strong positive loading on $\mathrm{DO}, \mathrm{T}^{\circ} \mathrm{C}$ and $\mathrm{Ph}$. The strong negative loading on $\mathrm{Cl}^{-}$in component 2. According to Component 3, 23.1\% of total variance has strong positive loading on $\mathrm{Ph}, \mathrm{NH}_{4}-\mathrm{N}, \mathrm{NO}_{2}-\mathrm{N}$ and $\mathrm{PO}_{4}-\mathrm{P}$. PCA analysis is a statistical analysis that indicates which parameters are more effective in data with many variables.

\section{Trichoptera Dataset}

In this study 10 genera of 6 families belonging to the subgroup of Trichoptera, Annulipalpia, Integripalpia and Scipipalpia, and 21 taxa related to these species were determined. A total of 1.367 individuals were examined. Diagnosis of some 7 genus samples could not be made due to the lack of sufficient resources in the larval diagnostic keys used or because the samples did not complete their development. Taxa given in genus level are Hydropsyche sp., Glossosoma sp., Agapetus sp., Hydroptila sp., Oxyethira sp., Rhyacophila sp. and Agraylea sp. The taxa of Trichoptera fauna determined in Ulupinar Stream and their distribution by stations are given in Table 3 . 
Table 3

Distributions of Trichoptera Taxa in the Stations

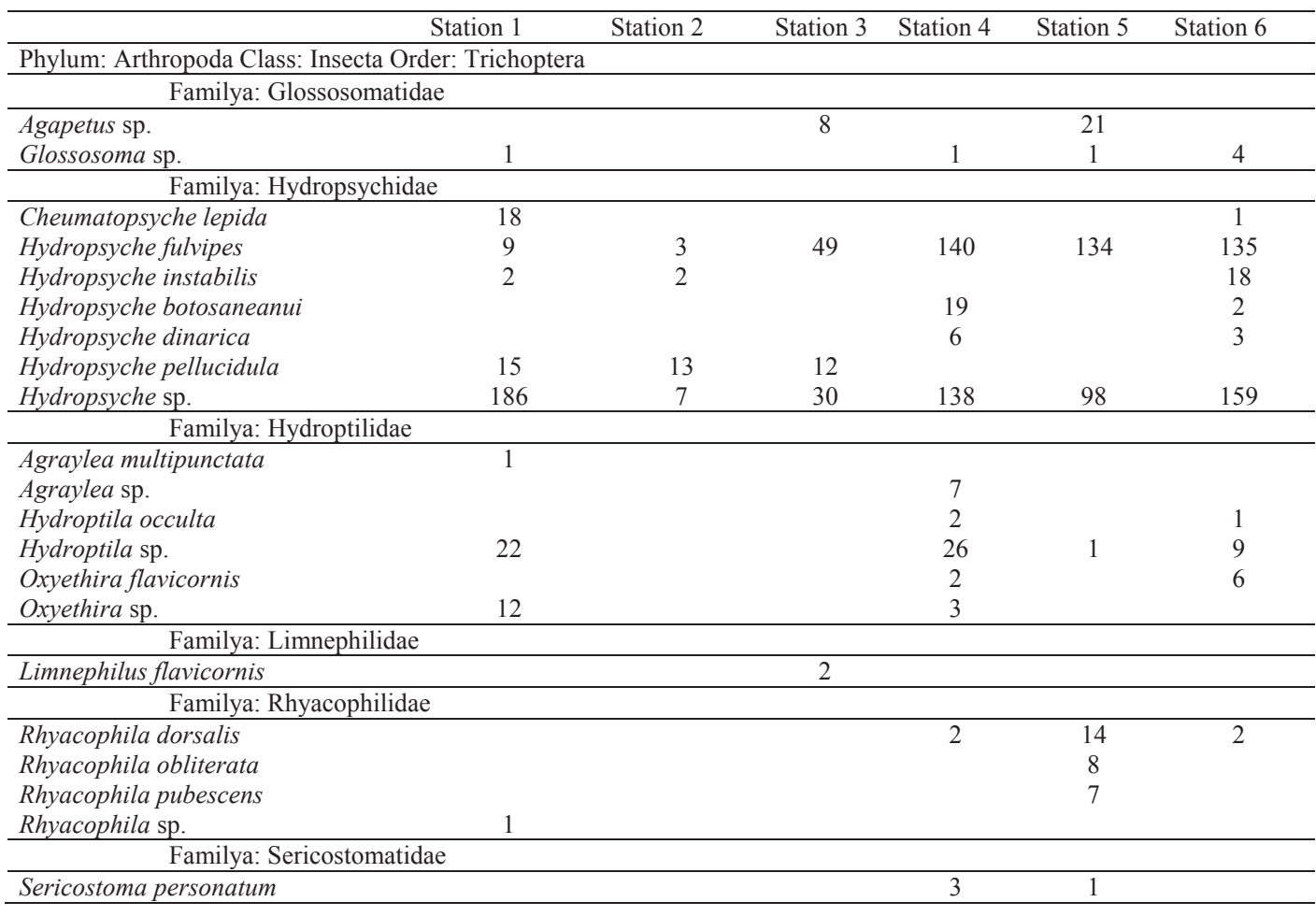

The highest number of individuals in Ulupinar Stream was determined at the $4^{\text {th }}$ station (349). In other stations, the ranking was $6^{\text {th }}$ station (340), $5^{\text {th }}$ station (285), $1^{\text {st }}$ station (267) and $3^{\text {rd }}$ station (101), and $2^{\text {nd }}$ station (25) with the lowest number of individuals.

In the $1^{\text {st }}$ station, 267 individuals belonging to a total of 10 taxa were examined. The species with the highest number of individuals is Hydropsyche sp. (186), while this taxon Hydroptila sp. (22), Cheumatopsyche lepida (18), Hydropsyche pellucidula (15), Oxyethira sp. (12) and Hydropsyche fulvipes (9), Glossosoma sp. (1), Rhyacophila sp. (1) and Agraylea multipunctata (1) followed the species.

In the $2^{\text {nd }}$ station, 25 individuals were identified and 13 of these individuals are belonging to Hydropsyche pellucidula, 7 individuals are belonging to Hydropsyche sp., 3 individuals are belonging to Hydropsyche fulvipes, and lastly 2 
individuals are belonging to Hydropsyche instabilis. At this station, a total of 4 taxa have been determined and it has the the least taxon among the other stations. Hydropsyche is the dominant breed both in terms of individual number and taxon number.

While determining 5 taxa at the $3^{\text {rd }}$ station, the taxon represented by the highest number of individuals was Hydropsyche fulvipes (49), followed by Hydropsyche sp. (30), Hydropsyche pellucidula (12), Agapetus sp. (8) and Limnephilus flavicornis (2).

The highest number of taxa (12) and the highest number of individuals (349) in Ulupinar Stream were determined in the $4^{\text {th }}$ station. In the $4^{\text {th }}$ station, taxa according to the number of individuals are Hydropsyche fulvipes (140), Hydropsyche sp. (138), Hydroptila sp. (26), Hydropsyche botosaneanui (19), Agraylea sp. (7), Hydropsyche dinarica (6), Oxyethira sp. (3), Sericostoma personatum (3), Hydroptila occulta (2), Oxyethira flavicornis (2), Rhyacophila dorsalis (2), Glossosoma sp.(1).

In the $5^{\text {th }}$ station, a total of 285 individuals belonging to 9 taxa have been identified and it takes third place in terms of number of individuals. Hydropsyche fulvipes (134) has the highest number of individuals among the determined taxa, whereas Hydropsyche sp. (98), Agapetus sp. (21), Rhyacophila dorsalis (14), Rhyacophila obliterata (8), Rhyacophila pubescens (7), Hydroptila sp. (1), Glossosoma sp. (1) and Sericostoma personatum (1) follow the taxa.

In the $6^{\text {th }}$ station, 11 taxa and 340 individuals belonging to the Trichoptera order were determined and ranked second among the stations in terms of the number of species. While the taxon with the highest number of individuals in this station is Hydropsyche sp. (159), this taxon is Hydropsyche fulvipes (135), Hydropsyche instabilis (18), Hydroptila sp. (9), Oxyethira flavicornis (6), Glossosoma sp. (4), Hydropsyche dinarica (3), Rhyacophila dorsalis (2), Hydropsyche botosaneanui (2) followed by Hydroptila occulta (1) and Cheumatopsyche lepida (1).

The classification of the stations based on benthic macroinvertebrates composition was illustrated by using Bray-Curtis UPGMA analysis (Figure 2). As a result of the UPGMA analysis, the 4th and 6th stations $(85 \%)$ were the most similar to each other. The second most similar stations to each other were determined at the 3rd and 5th stations $(83 \%)$. 
As a result of seasonal studies carried out in Ulupinar Stream between November 2015 and June 2016, 516 individuals were found in autumn (November), 239 individuals in winter (February), 452 individuals in spring (March) and 160 individuals in summer (June).

\section{Figure 2}

Classification of Stations Based on Similarities of in Ulupınar Stream

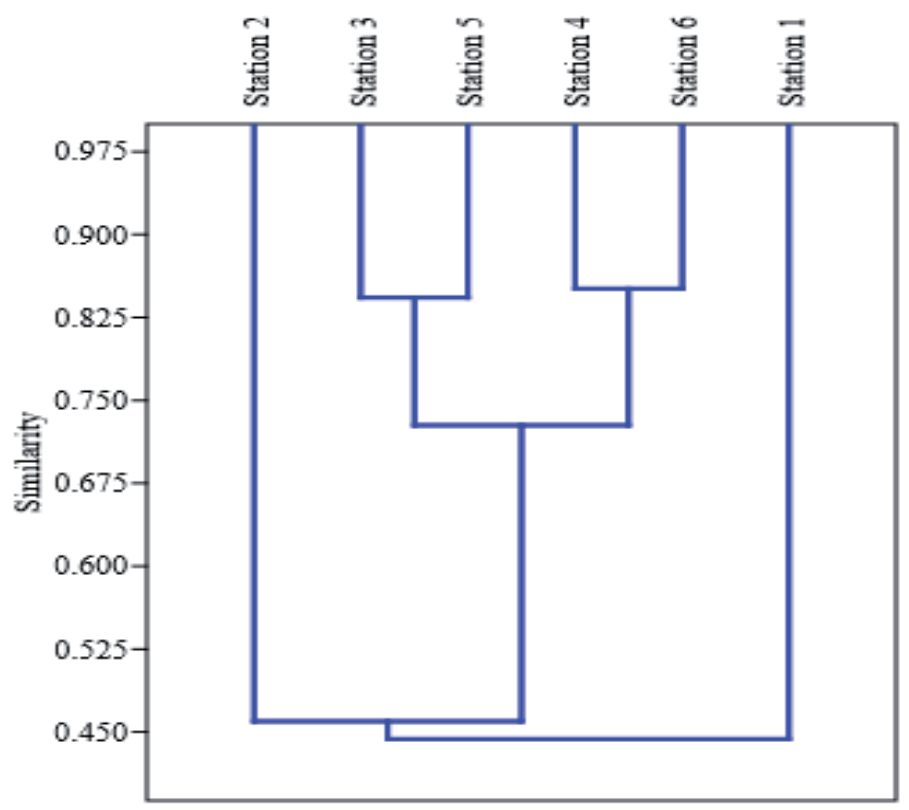

\section{Discussion and Conclusion}

In fact, water can dissolve certain amounts of oxygen. The ability of water for dissolving oxygen is related with its temperature. Therefore, the cold water dissolves, more oxgen and also is better for living organisms (Jens, 1980). The highest water temperature value was determined at sixth stations with $24.3^{\circ} \mathrm{C}$. In this period, the stream width decreased to $30 \mathrm{~cm}$ and depth to about $5 \mathrm{~cm}$. In this study, I found out that the amount of oxygen in Ulupinar Stream changed in parallel with the temperature changes and the flow rate in the stream was determined at very low levels during all sampling periods.

While some of the members of Trichoptera live in mountain streams with high oxygen content and low temperature, some are found in rivers and in lakes (Edington \& Hildrew, 1995). In this study, 11 species were identified in February, when the 
water temperature was the lowest. Chemical and biochemical reaction rates increase as the temperature increases. While organisms usually survive between certain temperature values, temperature changes cause increase and decrease in development and respiratory rates (Tchobanoglous \& Schroeder, 1985).

When the DO value falls below $0.5-1.0 \mathrm{mg} / \mathrm{L}$ in water, life in the water stops and values below $4 \mathrm{mg} / \mathrm{L}$ of DO cause negative effects on the development of living things (Goldwald, 1965; McNelly et al., 1979). Average DO values recorded at the six stations in Ulupınar Stream vary between $7.49 \mathrm{mg} / \mathrm{L}$ and $9.18 \mathrm{mg} / \mathrm{L}$. The highest DO value was determined as $9.99 \mathrm{mg} / \mathrm{L}$ at $5^{\text {th }}$ station, the lowest dissolved oxygen value was $6.01 \mathrm{mg} / \mathrm{L}$ at $6^{\text {th }}$ station. The lowest $\mathrm{T}^{\circ} \mathrm{C}$ value and the highest $\mathrm{DO}$ values were determined at the $5^{\text {th }}$ station. This situation shows that the DO values are inversely proportional. At the $6^{\text {th }}$ station, the flow rate is very slow, the amount of water is very low and the amount of DO is determined at the lowest levels due to the absence of shading.

In aquatic systems, living organisms have a tolerance to certain $\mathrm{pH}$ ranges and the $\mathrm{pH}$ value should vary between 6.5 and 8.5 in unpolluted natural waters (Hem, 1985; Barlas, 1988; Wetzel, 1983) because bicarbonate and carbonic acid work in buffering among these values (Barlas, 1988). Many natural waters are slightly alkaline because they contain carbonate and bicarbonate (Barlas, 2002). The $\mathrm{pH}$ value varies between 7.4 (station 1) and 8.5 (station 2) at all stations detected in Ulupinar Stream. According to the $\mathrm{pH}$ values, all stations are within the limits for living them and are included in the "Class-I" water quality class according to the WPCR.

Increased pollution in streams causes an increase in the EC values (Kara \& Çömlekçioğlu, 2004; Verep et al., 2005; Kalyoncu et al., 2005). The highest EC value at Ulupinar Stream during the study period was measured at the $6^{\text {th }}$ station in June $(500 \mu \mathrm{S} / \mathrm{cm})$. The lowest EC value was measured at the $5^{\text {th }}$ station $(356 \mu \mathrm{S} / \mathrm{cm})$ in March.

Almost all natural waters have a certain amount of $\mathrm{CI}^{-}$and the amount of $\mathrm{CI}^{-}$ in the beds with unchanged rocks may vary between $10-30 \mathrm{mg} / \mathrm{L}$ in natural spring waters (Barlas, 1988; Hütter, 1984). The average $\mathrm{CI}^{-}$measured at the six stations was $6.32 \mathrm{mg} / \mathrm{L}$ at the $3^{\text {rd }}$ station, while its highest value was $16.9 \mathrm{mg} / \mathrm{L}$ at the $6^{\text {th }}$ station. These values represent the first class water quality according to the scale of the Klee and WPCR and it is within the limits for natural spring waters. 
Ammonium content in water increases due to the deterioration of organic matter, especially organic fertilizer or inorganic fertilization, domestic and industrial wastewater (Egemen \& Sunlu, 1996). Ammonium nitrogen average values were measured below the analysis limits at all stations.

While $\mathrm{NO}_{3}-\mathrm{N}$ and $\mathrm{NO}_{2}-\mathrm{N}$ in the waters may naturally originate from some minerals, the main source is organic substances and nitrogen fertilizers. The increase in organic substances rises the concentration of $\mathrm{NO}_{3}-\mathrm{N}$ and $\mathrm{NO}_{2}-\mathrm{N}$, while decreases the amount of DO. Normally, $\mathrm{NO}_{2}-\mathrm{N}$ should not be present in drinking and using waters (Baltac1, 2000; Barlas, 2002; Egemen, 2006). The presence of $\mathrm{NO}_{2}-\mathrm{N}$ in waters is an indicator of pollution (Barlas, 2002). In all measurements made in Ulupinar Stream, $\mathrm{NO}_{2}-\mathrm{N}$ was found below the analysis limits. $\mathrm{NO}_{3}-\mathrm{N}$, which is seen as the most common form of nitrogen in rivers, is found in very small amounts in clean waters and is an important source of nitrogen for plants. As a result of the rainwater washing the agricultural land, the $\mathrm{NO}_{3}-\mathrm{N}$ originating from the fertilizers is easily dissolved in the water and mixed with the surface waters and streams (Barlas, 2002). The average $\mathrm{NO}_{3}-\mathrm{N}$ values in the six stations ranged from $0.22 \mathrm{mg} / \mathrm{L}$ to 1.2 $\mathrm{mg} / \mathrm{L}$.

$\mathrm{PO}_{4}-\mathrm{P}$ content is around $0.03 \mathrm{mg} / \mathrm{L}$ in mountain streams and streams not polluted. If this amount exceeds $0.1 \mathrm{mg} / \mathrm{L}$, contamination can be suspected (Höll, 1979). Domestic wastes, volcanic rocks and soil are among the sources of phosphorus (Baltac1, 2000; Tanyolaç, 2000; Egemen, 2006; Cirik \& Cirik, 2008). The $\mathrm{PO}_{4}-\mathrm{P}$ value remained below the analysis limits in all field studies carried out at six stations.

The amount of $\mathrm{BOI}_{5}$ in the oligosaprob region is $1.6 \mathrm{mg} / \mathrm{L}$ and it is below in natural waters. As a result of contamination, the $\mathrm{BOI}_{5}$ value increases and the amount of DO decreases (LAWA, 1980). While BOI5 values in streams yield the amount of organic matter, it provides the opportunity to compare the pollution rate between streams and stations (LAWA, 1980; Kocataş, 2008). While very high values were not determined in Ulupinar Stream, the highest BOI 5 was measured as $4.00 \mathrm{mg} / \mathrm{L}$ at the $4^{\text {th }}$ and $5^{\text {th }}$ stations. The existence of facilities and the effect of environmental pollution are reasons for the increase in values.

As a result of the evaluation made on physicochemical variables, according to Klee (1991), all stations were determined as the average value in the first quality class (oligosaprob-uncontaminated), while the first five stations were determined according to the WPCR in the case of the first quality class according to all 
parameters. According to the average value of DO, the water quality of the stream was determined as Class II.

Our study conducted on the Trichoptera fauna and water quality in Ulupinar Stream, is the new and recent study for this region. There is any study on Trichoptera fauna and water quality for Ulupinar Stream.

As a result of the studies carried out at the stations, Agraylea multipunctata species were found only at the $1^{\text {st }}$ station. The station has an altitude of $245 \mathrm{~m}$, the average $\mathrm{T}^{\circ} \mathrm{C}$ values varied between $10.9^{\circ} \mathrm{C}$ and $19.7^{\circ} \mathrm{C}$. The taxon found in the first station has a low flow rate in this study. According to Graf et al. (2008), this taxon prefers stagnant waters. According to DIN 38410 (2004), this taxon is dispersed in the betamesosaprob region and was determined in the first quality class in this study.

Cheumatopsyche lepida was found at the $1^{\text {st }}$ and $6^{\text {th }}$ stations. In the Ulupinar Stream, this species ranged between the lowest $54 \mathrm{~m}$ altitude and the highest $245 \mathrm{~m}$ altitude. The temperature values determined by this taxon varied between $10.9^{\circ} \mathrm{C}$ and $19.7^{\circ} \mathrm{C}$. Graf et al. (2008) stated that this taxon is seen in areas higher than $150 \mathrm{~m}$ and prefers high flow areas, and average temperature values are given between 8$20^{\circ} \mathrm{C}$. The results obtained from the heights matched up with the literature. According to DIN 38410 (2004), this taxon is an organism that spreads in the betamesosaprob region and it was found in the oligosaprob region in this study.

In the study, most individuals belong to the Hydropsychidae family. It is stated that the distribution of Hydropsychidae [H. fulvipes (Curtis, 1834), H. instabilis (Curtis, 1834), H. botosaneanui, H. dinarica, H. pellucidula (Curtis, 1834)] members, commonly known as a cosmopolitan family, may be different according to factors such as DO, $\mathrm{T}^{\circ} \mathrm{C}$, flow rate (Wiggins \& Mackay, 1978; Williams \& Feltmate, 1992).

Hydroptila occulta was found at the $4^{\text {th }}$ and $6^{\text {th }}$ stations and it was determined the average $\mathrm{T}^{\circ} \mathrm{C}$ values varied between $16,3^{\circ} \mathrm{C}$ and $19,5^{\circ} \mathrm{C}$ at the stations. In terms of altitude, it has been distributed in the stations with the altitude from $54 \mathrm{~m}$ to $201 \mathrm{~m}$. According to DIN 38410 (2004), Hydroptila taxa are among the organisms that spread in betamezosaprob region. Graf et al. (2008) stated that H. occulta is distributed between 150-1900 m altitudes and shows good development in stagnant waters with a temperature of $5^{\circ} \mathrm{C}-18^{\circ} \mathrm{C}$. Unlike the literature information, there are elevation and temperature differences in this stream. 
Limnephilus flavicornis was found only at the $3^{\text {rd }}$ station in summer (June). The average temperature of the station is $15^{\circ} \mathrm{C}$ and its altitude is $265 \mathrm{~m}$.

Oxyethira flavicornis was found at the $4^{\text {th }}$ and $6^{\text {th }}$ stations and it has an altitude from $54 \mathrm{~m}$ to $201 \mathrm{~m}$ and was determined at $16,3^{\circ} \mathrm{C}$ and $19,5^{\circ} \mathrm{C}$ in terms of average temperatures. Graf et al. (2008) stated that this taxon is distributed in the epirhitral, metarhitral and littoral regions of stagnant and slow flow streams at an altitude more than $150 \mathrm{~m}$.

Rhyacophila dorsalis species was found in the $4^{\text {th }}, 5^{\text {th }}$ and $6^{\text {th }}$ stations and the altitudes were determined at stations ranging from $54 \mathrm{~m}$ to $201 \mathrm{~m}$. The average temperature values of the stations varied between $13.9^{\circ} \mathrm{C}$ and $19.5^{\circ} \mathrm{C}$. While Aky1ldiz \& Duran (2008) express this taxon in Class IV, Keşir (2016) determines it in Class I and Class II quality classes. According to DIN 38410 (2004), these organisms are belonging to the betamesosaprob region. The results in this study reveal that it in Class I quality class. Kalyoncu et al. (2008) stated that they are distributed in Class I quality class.

Rhyacophila obliterata was detected only at $5^{\text {th }}$ station and only in February. The temperature of the station is between $12.5^{\circ} \mathrm{C}$ and $16.1^{\circ} \mathrm{C}$. The altitude was determined as $186 \mathrm{~m}$. According to DIN 38410 (2004), these organisms are belonging to the betamesosaprob region.

Rhyacophila pubescens was found only in $5^{\text {th }}$ station and in only November. The average temperature value of the station is $13.9^{\circ} \mathrm{C}$. The altitude value is $186 \mathrm{~m}$. According to DIN 38410 (2004), these organisms are belonging to the oligosaprob region.

Sericostoma personatum was found in the $4^{\text {th }}$ and $5^{\text {th }}$ stations. The temperatures of the stations varied between $12,1^{\circ} \mathrm{C}$ and $19,8^{\circ} \mathrm{C}$. It altitudes were between $186 \mathrm{~m}$ and $201 \mathrm{~m}$. Zeybek \& Şahin (2016) stated that this species spread in Munzur Stream. According to DIN 38410 (2004), these organisms are belonging to the oligobetamesosaprob region.

In the stream, Agapetus sp. was determined at the $3^{\text {rd }}$ and $5^{\text {th }}$ stations while Glossosoma sp. was determined at the $1^{\text {st }}, 4^{\text {th }}, 5^{\text {th }}$ and $6^{\text {th }}$ stations and they show the distribution in oligosaprob and oligo-betamesosaprob regions according to the saprobi index (DIN 38410, 2004). 
Agraylea sp. was determined only at the fourth station, Hydropsyche sp. was determined at all stations, Hydroptila sp. was determined at the first, fourth, fifth and sixth stations, Oxyethira sp. was determined at the first and fourth stations, Rhyacophila sp. was determined only at the first station. Rhyacophyla taxa are distributed between oligosaprob and betamesosaprob regions, but are generally organisms of the oligosaprob region (DIN 38410, 2004).

Taxa belonging to Trichoptera determined in this study are the new registration for this stream. Also, all stations are free from some or any contaminants in this stream, and according to Klee (1991), all stations are determined at the oligosaprob level. I can say that the organisms identified in these streams are distributed in clean or slightly contaminated freshwaters.

Although the majority of the organisms identified in this study distributed in clean or slightly contaminated river sections, species tolerant to organic pollution were also encountered. This may indicate that the working area and the organisms are under pollutant effects. Almost all of the Ulupinar Stream Basin has intense tourism activities. In addition, animal husbandry is done intensely in the region and it is known that the residues formed as a result of these activities are mostly poured into the nearest water environment and streams. Domestic wastes of small villages in the basin are also left uncontrolled to the streams and their surroundings. All these adverse conditions cause an increase in the pollution load of the river basin and affect the biodiversity of the basin as negatively. In this study, it was aimed to determine the Trichoptera fauna and the water quality of Ulupinar Stream. This and similar studies will contribute to establish Turkey's Trichoptera fauna and shed light on other systematic and ecological studies.

\section{Acknowledgement}

I would like to thank the General Directorate of Nature Conservation and National Parks of the Ministry of Forestry and Water Affairs, and Süleyman Demirel University Geothermal Energy, Groundwater and Mineral Resources Research and Application Center, which supported me in my work. In addition, I would like to thank the Presidency of Scientific Research Projects Management Unit of Süleyman Demirel University (BAP), which financially supported my thesis with Project No 4433-YL2-15. 


\section{References}

Akyıldız, G. K., \& Duran. M. (2011). Evaluating benthic macroinvertebrate fauna and water quality of Suleymanli Lake (Buldan-Denizli) in Turkey. Acta Zoologlca Bulgarlca, 63(2), 169-178. http://www.acta-zoologica-bulgarica.eu/downloads/acta-zoologica-bulgarica/2011/63-2169-178.pdf

Baltac1, F. (2000). Water Analysis Methods. Republic of Turkey Ministry of Energy and Natural Resources, State Hydraulic Works Water and Sewerage Department Printing and Photo-Film Branch Office.

Barlas, M. (1988). Limnological investigations on the Fulda with special consideration of the fish parasites, their host spectrum and the water quality [Doctoral dissertation, University of Kassel]. 138.

Barlas, M. (2002). Water Quality Determination Methods. Graduate Lecture Notes.

Çakın, F. (1983). Some New Species and Records of Trichoptera in Turkey. Aquatic Insects, 5(4), 233-249.

Cirik, S., \& Cirik, Ş. (2008). Limnology. Ege University Fisheries Faculty Publications, Ege University Press.

Darılmaz, M. C., \& Salur, A. (2015). Annotated catalogue of the Turkish Caddisflies (Insecta: Trichoptera). Munis Entomology \& Zoology, 10 (Suppl.), 521-734. https://www. munisentzool.org/Issue/abstract/annotated-catalogue-of-the-turkish-caddisflies-insectatrichoptera-994

DIN 38410. (2004). Biologisch-ökologische Gewässeruntersuchung (Gruppe M) - Teil 1: Allgemeine Hinweise, Planung und Durchführung von Fließgewässeruntersuchungen (M1) - Bestimmung des Saprobienindex (M1) Deutsche Einheitsverfahren zur Wasser-, Abwasser- und Schlammuntersuchung, Ausgabe 2004-10. https://dx.doi.org/10.31030/9569530

Edington, J. M., \& Hildrew, A. G. (1995). Caseless Caddis Larvae of the British Isles. Freshwater Biological Association Scientific Publication.

Egemen, Ö. (2006). Water Quality. Ege University Press.

Egemen, Ö., \& Sunlu, U. (1996). Water Quality (Textbook). Ege University Faculty of Fisheries Publication No: 14, Ege University Press.

Goldwald, S.T. (1965). The egg influx of temporary oxygen deficiency in various stages on the embryonic development of the rainbow trout (Salma gairdneri). Z. Fischerei, 13, 63-84.

Graf, W., Murphy, J., Dahl, J., Zamora-Muñoz, C., \& López-Rodríguez M.J. (2008). Distribution and ecological preferences of European freshwater organisms in Trichoptera (A. Schmidt Kloiber, and D. Hering Eds., Vol. 1). Sofia-Moscow: Pensoft Publishers. 
Höll, K. (1979). Wasser (Untersuchung, Beurteilung, Aufberaitung, Chemie, Bacteriologie, Virologie, Biologie) 6. Auflage de Gruyter Berlin, New York.

Hem, J. D. (1985). Study and Interpretation, of the chemical characteristics of natural water $\left(^{\text {rd }}\right.$ ed.). United States Government Printing Office.

Hütter, L. A. (1984). Water and water analysis ( $2^{\text {nd }}$ ed.). Diesterweg Salle Sauerlander.

Jens, G. (1980). This is how you pull trout. ( ${ }^{\text {th }}$ ed.)Verlag Paul Parey Hamburg-Berlin.

Kalyoncu, H., Barlas, M., Ertan, O.O., \& Çavuşoğlu, K. (2005). A study on the change of water quality of Aksu Stream. Süleyman Demirel University Journal of the Institute of Science, 9 (1), 5 13.

Kalyoncu, H., Yorulmaz, B., Barlas, M., Yıldırım, M. Z., \& Zeybek, M. (2008). The effect of water quality and physicochemical parameters of Aksu Stream on macroinvertebrate diversity. Firat University Journal of Science and Engineering Sciences, 20 (1), 23-33. https://www.researchgate.net/profile/Melek_Zeybek/publication/270509324_Aksu_Cayi'ni n_Su_Kalitesi_ve_Fizikokimyasal_Parametrelerinin_Makroomurgasiz_Cesitliligi_Uzerine _Etkisi/links/54ac2ab10cf23c69a2b76a00.pdf

Kara, C., \& Çömlekçioğlu, U. (2004). Investigation of Karaçay (Kahramanmaraş) pollution with biological and physicochemical parameters. Kahramanmaraş Sutcu Imam University Science and Engineering Journal, 7(1), 1-7.

Kazi, T. G., Arain, M. B., Jamali, M. K., Jalbani, N., Afridi, H. I., Sarfraz, R. A., Baig, J. A, \& Shah A. Q. (2009). Assessment of water quality of polluted lake using multivariate statistical techniques: A case study. Ecotoxicology and Environmental Safety, 72(2), 301-309. https://doi.org/10.1016/j.ecoenv.2008.02.024

Keşir, Ü. E. (2016). Ceyhan River Trichoptera fauna (2016-01) [Master's thesis. Nevşehir Hacı Bektaş Veli University, Institute of Science].. http://hdl.handle.net/20.500.11787/234

Klee, O. (1991). Applied hydrobiology (2 $2^{\text {nd }}$ ed.)Stuttgart-New York: G. Thieme Verlag.

Kocataş, A. (2008). Ecology and environmental biology (10 ${ }^{\text {th }}$ ed.) Ege University Faculty of Science Textbooks Series.

Küçükbasmacı, İ., \& Kıyak, S. (2017). A study on the caddisfly fauna (Insecta: Trichoptera) of Kastamonu and a new species record for Turkey. Munis Entomology \& Zoology, 12(2), 486-499. file:///C:/Users/s.ozturk/Downloads/vol12issue2-4560358.pdf

Länder-Arbeitsgemeinschaft Wasser (LAWA). (1980). The water quality map of the Federal Republic of Germany. Stuttgart, 16.

Liu, C. W., Lin, K. H., \& Kuo, Y. M. (2003). Application of factor analysis in the assessment of groundwater quality in a Blackfoot disease area in Taiwan. Science of the Total Environment, 313(1-3): 77-89. https://doi.org/10.1016/s0048-9697(02)00683-6 
McNelly, R. N., Neimanis, V. P., \& Dwyer, L. (1979). Water quality source book, a guide to water quality parameters. Minister of Supply and Services, Canada, Catalog No: En37-54/1979, 89.

Morse, J. C. (2011). The Trichoptera world checklist. Zoosymposia, 5(1), 372-380. https://doi.org/10.11646/zoosymposia.5.1.29

Pauls, S. U., Graf, W., Haase, P., Lumbsch, H.T., \& Waringer, J. (2008). Grazers, shredders and filtering carnivores-the evolution of feeding ecology in Drusinae (Trichoptera: Limnephilidae): insights from a molecular phylogeny. Molecular Phylogenetics Evoluation, 46(2), 776-791. https://dx.doi.org/10.1016\%2Fj.ympev.2007.11.003

Pescador, M. L., Rasmussen, A. K., \& Haris, S. C. (1995). Identification manual for the caddisfly (Trichoptera) larvae of Florida. State of Florida Department of Environmental Protection Division of Water Facilities Final Report, 5-46. http://nebula.wsimg.com/401744dfea0fbc1 e94c65722a00f0960?AccessKeyId=95B4E6FC9C D3AA32E410\&alloworigin $=1 \&$ disposition $=0$

Pitsch, T. (1993). On the larval taxonomy, faunistics and ecology of Central European flowing water caddis flies (Insecta: Trichoptera). Series of Publications by the Department of Landscape Development, special issue 8.

Sipahiler, F. (2018a). Three new species of caddisflies (Trichoptera: Hydroptilidae, leptoceridae) from Turkey and faunistic list for the Seyhan and Ceyhan rivers. Nova Acta Cientifica Compostelana (Bioloxía), 25, 37- 43.

Solanki, S. K., Barthol, P., Danilovic, S., Feller, A., Gandorfer, A., Hirzberger, J., Riethmüller, T. L., Schüssler, M., Bonet, J. A., Martínez Pillet, V., del Toro Iniesta, J. C., Domingo, V., Palacios, J., Knölker, M., Bello González, N., Berkefeld, T., Franz, M., Schmidt, W., \& Title, A. M., (2010). The Astrophysical Journal Letters, 723(2). https://iopscience.iop.org/article/10.1088/20418205/723/2/L127/meta

Somerfield. P. J. (2008). Identification of the Bray-Curtis similarity index: Comment on Yoshioka. Marine Ecology Progress Series, 372, 303-306. https://doi.org/10.3354/meps07841

Su Kirliliği Kontrolü Yönetmeliği. (2008). https://www.mevzuat.gov.tr/mevzuat?MevzuatNo= 7221\&Mevzuat Tur=7\&Mevzuat Tertip $=5$

Tanyolaç, J. (2000). Limnology. Hatiboğlu Publishing.

Tchobanoglous, G., \& Schroeder, E.D. (1985).Water Quality. Mass.Addison-Wesley, 768.

Turkish Regulation for Water Pollution Control (WPCR). (2008). https://www.mevzuat.gov.tr/mevzuat?MevzuatNo=7221\&MevzuatTur=7\&MevzuatTertip $=5$ 
Verep, B., Serdar, O., Turan, D., \& Sahin, C. (2005). Determination of water quality in terms of physico- chemical structure of the River Iyidere (Trabzon). Ekoloji, 15(57), 7-16. https://app.trdizin.gov.tr/dokumangoruntule?ext=pdf\&path=CrnWZGRsXTjRjLjWxD978OSUAL2jXitizhVYmCxNvH5Cjr AQA9r3JaSPje04xcPgVNHGqmsNjA2xtdL48IEPvll3ASd6GINm8_vTAp1C53KyiMeTjBj fBH5yMPhI6AUIvUyzBzbqnDRI8kb2zU3mhLLQRFvDgKLEexwvDxC4CDp7pDKhsls4p w3wBQkQiB9wmSRVLwwNf_Iqjbjvi8HTnoa114xvYu1jxYQpDC47fU0=\&contentType=a pplication/pdf

Wallace, A., Wallace, G.A., \& Cha, J.W. (1990). Soil organic matter and the global carbon cycle. Journal of Plant Nutrition, 13,459-466.

Waringer, J., \& Graf, W. (2011). Atlas of Central European Trichoptera Larvae. Erik Mauch Publishers.

Wetzel, R. G. (1983). Limnology. Sounders College Publishing.

Wiggins, G. B. (1998). Larvae of the North American Caddisfly Genera (Trichoptera) (2 ${ }^{\text {nd }}$ ed.). University of Toronto Press.

Wiggins, G. B., \& Mackay, R. J. (1978). Some relationships between systematics and trophic ecologyin nearctic aquatic insects. Ecology, 59, $1211-1220$.

Williams, D., \& Feltmate, B. (1992). Aquatıc Insects, CAB International, Wallingford.

Yoshioka, P. M. (2008). Misidentification of the Bray-Curtis similarity index. Marine Ecology Progress Series, 368,309-310. https://doi.org/10.3354/meps07728

Zeybek, M., \& Koşal-Şahin, S. (2016). The Distribution of Trichoptera Assemblages In Relation To Environmental Variables in the Streams of Tunceli (Turkey). Fresenius Environmental Bulletin, 25(11), 4972-4981. 


\section{Extended Turkish Abstract (Genişletilmiş Türkçe Özet)}

\section{Ulupınar Çayı’nın Trichoptera Faunası ve Su Kalitesi ile İlişskisi}

Su canlıların yaşaması için gerekli olan temel ihtiyaçlardandır. Su kaynaklarında günden güne meydana gelen çeşitli sorunlar geri dönüşü olmayacak şekilde su kıtlı̆̆ına neden olmaktadır. Avrupa Birliği üyesi ülkeler, su kaynaklarının kalite ve miktar yönünden incelenmesi ve korunmasını hedeflemiştir. Aynı zamanda yeraltı ve yerüstü tüm yüzey sularının korunması ve izleme programlarının geliştirilmesi, tüm suların iyi kalite su sınıfına (iyi durum) yükseltilmesini, biyolojik, kimyasal, hidrolojik ve morfolojik açılardan su kalitesinin tanımlanması, nehir havzaları temelinde su yönetiminin oluşturulması, ekonomik enstrümanların, ekonomik analizlerin ve suyun kullanımına dair doğru ekonomik yaklaşımların geliştirilmesi ve geliştirilen nehir havzası yönetimi planlarına vatandaşların, belediyelerin, sivil toplum örgütlerinin zorunlu kamusal katılımın sağlanması gibi birçok hedefleri gerçekleştirmeyi amaçlayarak Su Çerçeve Direktifini (SÇD) hazırlamışlardır. Su ile ilgili tüm unsurları bir çatı altında toplayan SÇD sayesinde su kalitesi, su kütlelerinin ekolojik ve kimyasal özelliklerine göre tespit edilir. Biyolojik kalite unsurlarının durumu suyun biyolojik kalitesi hakkında bizlere bilgi verir.

Daha önce üzerinde çalışma yapılmamış olan Ulupınar Çayı (Antalya) inceleme alanı olarak seçilmiştir. Bu araştırmayı yapma amacımız Ulupınar Çayı'nda bulunan Triphoptera faunasını belirlemek ve belirlenen faunaya göre suyun kirliliğini saptamaktır. Aynı zamanda yapılan fizikokimyasal ölçümlere göre bölgenin kirlilik ile ilgili net sonuçlarına ulaşılmaktır. Trichoptera takımı her tip tatlı su habitatında yaşamaları ve balıklara besin kaynağı olmalarından dolayı su ekosisteminin temel canlıları arasında yer almaktadır. Trıchoptera takımı hızlı akan sularda bulunmakta, aynı zamanda bulunduğu bölgenin ekolojik yapısı hakkında araştırmacılara bilgi vermekte ve kirliliğe karşı duyarlılık göstermektedirler.

Ulupınar Çayı'nda Kasım 2015 - Haziran 2016 tarihleri arasında yapılan çalışmada Trichoptera faunasını ve su kalitesini belirleyebilmek amacıyla arazi şartlarının uygunluğuna göre 6 istasyon seçilmiştir. İstasyonlar akarsudaki karışımları ve etkileşimi yansıtacak şekilde tespit edilmiş ve sürekli akış gösteren yan kollar dikkate alınmıştır. İstasyonların koordinatları ve rakımları GPS yardımı ile ölçülmüştür. Belirlenen istasyonlarda mevsimsel olarak fizikokimyasal su analizi ve Trichoptera takımına ait organizmaların belirlenmesi için örnekler alınmış ve incelenmesi yapılmıştır. Su örnekleri için koyu renkli 1 litrelik polietilen örnek alma kaplarından yararlanılmıştır. Yapılan örneklemelerin yaklaşık olarak aynı saatlerde alınmasına dikkat edilmiştir. Su sıcaklığı $\left({ }^{\circ} \mathrm{C}\right), \mathrm{pH}$ değeri, elektrik iletkenliği $(\mu \mathrm{S} / \mathrm{cm})$ ve çözünmüş oksijen $\left(\mathrm{mgO}_{2} / \mathrm{l}\right)$ ölçümleri arazide portatif multiparametre (YSI 550A) cihazı kullanılarak yapılmıştır. Amonyum azotu $\left(\mathrm{NH}_{4}{ }^{+}-\mathrm{N}\right)$, Nitrit azotu $\left(\mathrm{NO}_{2}{ }^{-}-\mathrm{N}\right)$, Nitrat azotu $\left(\mathrm{NO}_{3}{ }^{-}-\mathrm{N}\right)$, Orto-fosfat iyonu $\left(\mathrm{PO}_{4}-\mathrm{P}\right)$, Klorür İyonu $\left(\mathrm{Cl}^{-}\right)$, Biyokimyasal Oksijen İhtiyac1 $\left(\mathrm{BOI}_{5}\right)$ analizleri $\left(\mathrm{mgO}_{2} / \mathrm{l}\right)$ Süleyman Demirel Üniversitesi Jeotermal Enerji, Yeraltı Suyu ve Mineral Kaynakları Araştırma ve Uygulama Merkezi'nde yaptııılmıştır. Fizikokimyasal değişkenler üzerinden yapılan değerlendirme sonucunda Klee (1991)'ye göre tüm istasyonlar ortalama değer olarak I. kalite sınıfında (oligosaprob-Kirlenmemiş), Su Kirliliği Kontrolü Yönetmeliği'ne (SKKY, 2008) göre yapılan değerlendirmede ilk 5 istasyon tüm parametrelere göre I. kalite sınıfı durumunda belirlenirken sadece 6 . istasyon çözünmüş oksijen ortalama değerine göre II. kalite sınıfında belirlenmiştir. 
Ölçüm yapılan fizikokimyasal verilerle türler arasındaki ilişki belirlenmeye çalışılmıştır. Sıklık, baskınlık ve benzerlik analizleri incelenerek Ulupınar Çayı'nın su kalitesi hakkında değerlendirme yapılmaya çalışılmıştır. Ulupınar Çayı'nda uygulanan benzerlik indeksi sonuçlarına göre en yüksek benzerlik IV. ve VI. istasyonlar arasında $(0,78)$ görülmüsstür.

Yapılan çalışmada Trichoptera takımına ait Annulipalpia, Integripalpia ve Scipipalpia alttakımlarına bağl1, 6 familyaya ait 10 cins ve bu cinslere bağlı 21 tür tespit edilmiştir. Toplam 1367 birey incelenmiştir. 7 cinse ait bazı örnekler teşhisi, kullanılan larva teşhis anahtarları içerisinde yeterli kaynak bulunmaması ya da örneklerin gelişimlerini tamamlamamış olması nedeniyle yapılamamıştır. Cins düzeyinde verilen taksonlar Hydropsyche sp., Glossosoma sp., Agapetus sp., Hydroptila sp., Oxyethira sp., Rhyacophila sp. ve Agraylea sp.' dir.

Toplanan örneklerin mevsimsel dağılımına bakıldığında, Kasım ayında 9 takson, Şubat ayında 11 takson, Mart ayında 12 takson ve Haziran ayında 12 takson belirlenmiş, en az takson sayısı Kasım döneminde tespit edilmiştir. Bu taksonların istasyonlara göre dağılımlarında ise 1 . istasyonda 10 takson, 2. istasyonda 4 takson, 3. istasyonda 5 takson, 4. istasyonda 12 takson, 5 . istasyonda 9 takson, 6. istasyonda 11 taksona rastlanmıştır. En fazla takson 4. istasyonda belirlenirken en az takson 2. istasyonda bulunmuştur.

Saprobi İndeks'e (DIN 38410, 2004) göre Trichoptera faunasının kalite sınıf aralığ oligosaprob ile Beta-Alfamesosaprob arasında değişim göstermektedir. Bu sınırlar saprobi indeksin kalite sınıflandırması olarak I. kalite sınıfı ile II-III. kalite sınıfı arasında değişim göstermektedir. Saprobi değeri olarak en yüksek değere Cyrnus trimaculatus $(2,5)$ sahip olurken çok az Trichoptera taksonu 2,3 saprobi değeri üzerine çıkmaktadır. Hydropsyche cinsinden ise sadece Hydropsyche contubernalis $(2,4)$ beta-alfamesosaprob yani II-III. kalite sınıfina dahil olmakta, Trichoptera takımından hiçbir organizma III., III-IV. ve IV. kalite sınıflarında dağılım göstermemektedir (DIN38410, 2004). Trichoptera takımının üyeleri arasında tüm indekslere göre Hydropsychidae familyası ve familya üyeleri en toleranslı taksonlar durumundadır. Klee (1991)'nin metodu ile fiziksel ve kimyasal parametreler kullanılarak ortalama su kalitesi değerlendirmesi yapılmıştır. Bu değerlendirme sonucunda tüm istasyonlar I. kalite seviyesinde (Oligosaprob) olduğu belirlenmişti. Akarsu üzerinde turizm baskısı olmasına ve balık çiftliklerinin varlığına rağmen akarsu oligosabrob düzeyde belirlenmiştir.

Ulupınar Çayı'nda belirlenen Trichoptera'ya ait taksonlar bu akarsu için yeni kayıt durumundadır. Bu akarsularda belirlenen organizmalar temiz veya az kirlenmiş akarsu bölümlerinde dağılış gösteren organizmalar olduğu söylenebilir. 